Postmodernism and Japan 


\section{Post-Contemporary}

Interventions

SERIES EDITORS:

STANLEY FISH AND

FREDRIC JAMESON 


\title{
Postmodernism and Japan
}

\author{
Edited by \\ Masao Miyoshi \\ and $H$. D. Harootunian
}

Duke University Press

Durham and London 
(C) 1989 Duke University Press

All rights reserved

Printed in the United States of America

on acid-free paper $\infty$

Fifth printing, 2003

Library of Congress Cataloging-in-Publication

Data appear on the last printed page of this book.

The majority of this text was originally

published in Japanese in Gendai shiso: revue de la pénsee d'aujourd'hui, Volume 15, December 1987 by Seitosha Publishing as "Problems of Postmodernity." It was subsequently published in English as Volume 87, Number 3 (Summer 1988) of The South Atlantic Quarterly. Articles by Isozaki Arata and Ōe Kenzaburō, as well as the index, have been added. 